\title{
A Biological Age Model Designed for Health Promotion Interventions: Protocol for an Interdisciplinary Study for Model Development
}

Karina Louise Skov Husted ${ }^{1,2}$, MSc, PT; Mathilde Fogelstrøm ${ }^{1}$, MSc; Pernille Hulst ${ }^{1}$, MSc; Andreas Brink-Kjær ${ }^{3}$, MSc; Kaj-Åge Henneberg ${ }^{4}$, PhD; Helge Bjarup Dissing Sorensen ${ }^{3}$, PhD; Flemming Dela ${ }^{1,5}$, MD, DMSci; Jørn Wulff Helge $^{1}, \mathrm{PhD}$

\footnotetext{
${ }^{1}$ Xlab, Center for Healthy Aging, Department of Biomedical Sciences, University of Copenhagen, Copenhagen, Denmark

${ }^{2}$ Department of Physiotherapy and Occupational therapy, University College Copenhagen, Copenhagen, Denmark

${ }^{3}$ Digital Health, Department of Health Technology, Technical University of Denmark, Kongens Lyngby, Denmark

${ }^{4}$ Biomedical Engineering, Department of Health Technology, Technical University of Denmark, Kongens Lyngby, Denmark

${ }^{5}$ Department of Geriatrics, Bispebjerg and Frederiksberg Hospital, Copenhagen, Denmark
}

\section{Corresponding Author:}

Karina Louise Skov Husted, MSc, PT

Xlab, Center for Healthy Aging

Department of Biomedical Sciences

University of Copenhagen

Blegdamsvej 3

Copenhagen, 2200

Denmark

Phone: 4535327423

Email: karinalu@sund.ku.dk

\section{Abstract}

Background: Actions to improve healthy aging and delay morbidity are crucial, given the global aging population. We believe that biological age estimation can help promote the health of the general population. Biological age reflects the heterogeneity in functional status and vulnerability to disease that chronological age cannot. Thus, biological age assessment is a tool that provides an intuitively meaningful outcome for the general population, and as such, facilitates our understanding of the extent to which lifestyle can increase health span.

Objective: This interdisciplinary study intends to develop a biological age model and explore its usefulness.

Methods: The model development comprised three consecutive phases: (1) conducting a cross-sectional study to gather candidate biomarkers from 100 individuals representing normal healthy aging people (the derivation cohort); (2) estimating the biological age using principal component analysis; and (3) testing the clinical use of the model in a validation cohort of overweight adults attending a lifestyle intervention course.

Results: We completed the data collection and analysis of the cross-sectional study, and the initial results of the principal component analysis are ready. Interpretation and refinement of the model is ongoing. Recruitment to the validation cohort is forthcoming. We expect the results to be published by December 2021.

Conclusions: We expect the biological age model to be a useful indicator of disease risk and metabolic risk, and further research should focus on validating the model on a larger scale.

Trial Registration: ClinicalTrials.gov NCT03680768, https://clinicaltrials.gov/ct2/show/NCT03680768 (Phase 1 study); NCT04279366 https://clinicaltrials.gov/ct2/show/NCT04279366 (Phase 3 study).

International Registered Report Identifier (IRRID): DERR1-10.2196/19209

(JMIR Res Protoc 2020;9(10):e19209) doi: 10.2196/19209

\section{KEYWORDS}

biological age; health promotion; protocol; healthy aging; principal component analysis 


\section{Introduction}

Healthy aging is of paramount importance when considering the trajectory of future aging populations $[1,2]$. Healthy aging refers to a healthy aging phenotype constituting a course of aging with high autonomy, no major chronic diseases, high quality of life, and an extended health span [3,4]. Following a healthy lifestyle earlier in life (eg, consuming alcohol moderately, not smoking, maintaining a healthy diet, and conducting regular physical activity) improves the chances of healthy aging $[5,6]$. Unfortunately, the steady increase in the prevalence of overweight and obesity in parallel with insufficient physical activity threatens healthy aging and emphasizes the need for effective health promotion of the general population [7-9].

Development of health literacy is a key element to promote a healthy lifestyle in the general population [10]. Applying various forms of health screenings, such as health risk assessment and health checks, is one way to track health status and thereby enable people to make qualified health decisions before diseases are manifested or progress. However, while knowledge is an important factor, it may not, by itself, motivate a change in lifestyle behavior. Health screenings often include measurements of well-established risk factors such as blood cholesterol, fasting blood glucose, and waist circumference. Although some people can understand the risk connected with these risk factors, they may be unaware of the extent to which their lifestyle affects their capability of maintaining youthful vigor and delaying morbidity to an older age. Such awareness might be pivotal and motivate changes in health behavior. Biological age plays a key role in this respect. We suggest that being "older" than stated on one's birth certificate readily translates into disease and mortality risks, and is thus effective as health literacy to improve people's lifestyles. In addition, we propose that biological age can be used as an outcome measure to quantify the overall placement of an individual on the healthy aging trajectory and their susceptibility to disease, which are useful in the context of primary and secondary health promotion interventions.

Unlike chronological age, biological age assesses the heterogeneity in functional metabolic status and vulnerability to disease. The increase in chronological age is uniform, whereas biological age can increase more rapidly for some and slower for others. This is due to nonmodifiable factors, such as genetics, and modifiable factors, such as lifestyle (smoking, diet, physical activity, etc) $[11,12]$. Biological age has been studied since the 1960s $[13,14]$. Much research has been directed toward finding the best biomarkers of aging [15,16] as well as the optimal method to estimate biological age $[17,18]$. Studies have shown that biological age can predict mortality better than chronological age and incidence of age-related diseases such as cardiovascular disease (CVD) and type 2 diabetes mellitus (T2DM) [18,19]. These results were obtained from large cross-sectional data and were derived statistically. Moreover, these studies rarely investigated the clinical use of the model in health promotion interventions.

This study aims to develop a biological age model that can distinguish between healthy and unhealthy aging among individuals with the same chronological age and sex, and investigate its clinical applicability. We apply acknowledged mathematical methodology to estimate biological age; use a combination of commonly used biological age modelling biomarkers that are minimally invasive, represent healthy aging [20], and denote the processes that change with age [15]; and explore their usefulness.

\section{Methods}

\section{Overview}

When developing a biological age model, it is optimal to combine knowledge of integrative physiology and health technology. Thus, our approach is interdisciplinary and involves expertise in human physiology, healthy aging, prediction modeling, and human data science.

This study protocol comprises three consecutive phases: (1) conducting a cross-sectional study to gather indicators from 100 individuals representing normal healthy aging (the derivation cohort); (2) defining a novel biological age model and estimating biological age using principal component analysis; and (3) investigating the clinical use of the model in a validation cohort of overweight adults attending a lifestyle intervention course.

\section{Phase 1: Derivation Cohort}

\section{Study Design}

We recruited 100 healthy individuals equally distributed in sex and evenly spread out within the age range of $18-65$ years. It is difficult to distinguish normal aging from pathological aging because physiological and functional decrements (or pathological changes) at the outset of a disease occurs as part of the normal aging process. Considering this, we excluded individuals with a history of previous or current CVD, and using medicine to reduce blood pressure, cholesterol, or glucose levels. Pregnancy is marked by physiological dynamics and is very different from the nonpregnant state (eg, the blood volume increases in the former) [21]. Thus, pregnant women or women who breastfeed were excluded from participation. In addition, people with conditions that would prevent them from enduring the cycle exercise and strength tests (eg, knee osteoarthritis) were also excluded. The study was approved by the Regional Ethics Committee, Copenhagen, Denmark (H-18031350) and was performed in accordance with the Helsinki Declaration. The study was recorded as a clinical trial (NCT03680768).

\section{Candidate Biological Age Model Biomarkers}

Eligible women and men arrived at the laboratory for a 2-hour examination after fasting overnight and abstaining from vigorous exercise in the prior 24 hours. The examination involved measuring 50 parameters to assess the health of the participants and collecting candidate biomarkers for the biological age model. Thus, the examination included measures of anthropometrics, physiological and metabolic health, and physical capacity as well as answering quality of life and daily physical activity questionnaires.

When selecting candidate biomarkers for the biological age model, we focused on variables that (1) characterize features 
of the healthy aging phenotype [20], (2) are associated with aging and age-related diseases, (3) are affected by lifestyle, and (4) are possible to obtain in a variety of settings (ie, that are not limited to use in a research setting).

Due to the mathematical approach used to estimate biological age, binary/discrete variables (eg, quality of life and education level) were not considered for the biological age model although we recognize that some of these variables are important for assessing social and mental wellbeing in the healthy aging phenotype [3].

In total, 32 variables were selected as candidate biomarkers and categorized in the following 6 domains: (1) body composition, (2) metabolic health, (3) cell blood count, (4) cardiorespiratory function, (5) physical capacity, and (6) immune function (Figure 1).

Figure 1. Candidate biomarkers proposed for the BA model. Each square represents 1 of the 6 following domains: (1) Body composition, (2) metabolic health, (3) cell blood count, (4) cardiorespiratory function, (5) physical capacity, and (6) immune function. The candidate biomarkers for the BA model are listed within each domain. AGE: advanced glycation end products; CHOL: Total cholesterol; CHOL/HDL: HDL to CHOL ratio; DBP: Diastolic blood pressure; $\mathrm{FEV}_{1}$ : Forced expiratory volume within 1 second; $\mathrm{FEV}_{1} / \mathrm{FVC}$ : FEV $\mathrm{F}_{1}-\mathrm{FVC}$ ratio; FFA: Free fatty acids; FVC: Forced vital capacity; $\mathrm{Hb}_{\mathrm{Alc}}$ : Glycated hemoglobin; HC: Hip circumference; HDL: High-density lipoprotein; hsCRP: High-sensitive C-reactive protein; LDL: Low-density lipoprotein; SBP: Systolic blood pressure; TG: Triglycerides; suPAR: soluble urokinase Plasminogen Activator Receptor; $\mathrm{VO}_{2 \mathrm{max}}$ : Maximal oxygen uptake; WC: Waist circumference; W/H: waist to hip ratio.

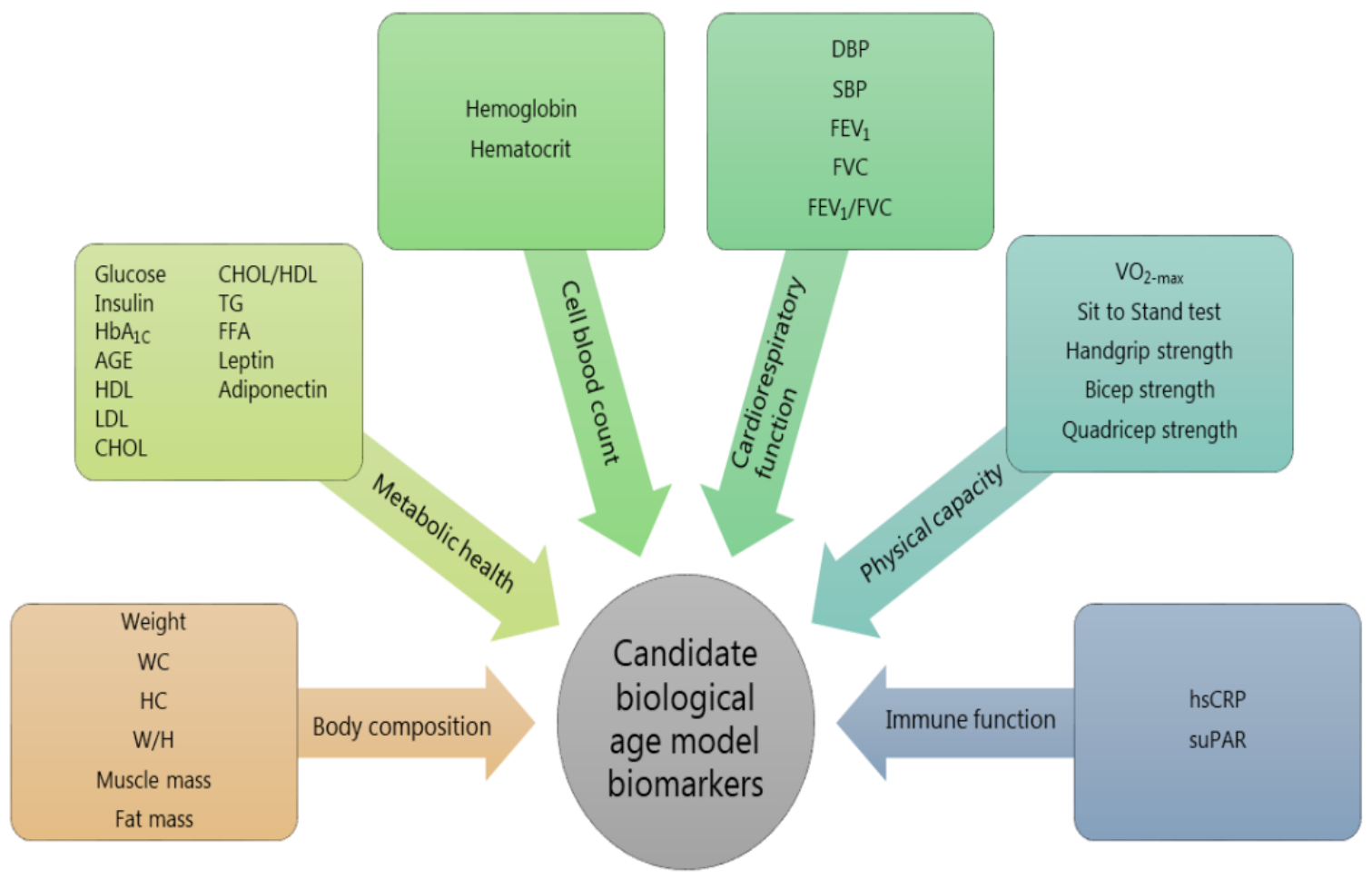

\section{Relevance of Domains}

In this section, we outline the variables included as possible biomarkers for the biological age model. We describe the variables and explain their relevance in a model that assesses healthy aging.

\section{Body Composition}

Aging is associated with loss of muscle mass and strength (sarcopenia) and an increase in fat mass and central adiposity. Muscle mass has been reported to begin showing a negative association with age as early as 27 years [22], with the decline in strength exceeding that in muscle mass [23]. This characteristic is related to loss in muscle quality, gradual muscle denervation, loss of type 2 muscle fibers, reduced muscle capillary density, reduced oxidative capacity, and fat infiltration [24,25].
Excess fat mass, and especially fat distribution, are important risk factors for the development of CVD and T2DM. Waist circumference and hip to waist ratio are used as surrogate measures for central adiposity and visceral adipose tissue [26,27].

\section{Metabolic Health}

Aging and unhealthy lifestyle are associated with reduced glucose homeostasis [28]. Fasting blood glucose concentration, $\mathrm{HbA}_{1 \mathrm{c}}$, and insulin sensitivity are markers of glucose homeostasis and are associated with incidence of CVD, T2DM, and mortality [20]. The prevalence of metabolic syndrome (a cluster of risk factors for T2DM and CVD) increases with age $[29,30]$. According to the International Diabetes Federation, the risk factors of metabolic syndrome are central obesity and any two of the following: raised triglyceride concentrations, reduced 
high-density lipoprotein concentrations, raised blood pressure, and raised fasting plasma glucose concentration [31]. The increase in metabolic syndrome prevalence observed with aging is associated with the age-related redistribution of fat, particularly increased central adiposity. Low levels of adiponectin are induced by visceral fat accumulation, recognized as a risk factor for CVD and T2DM, and associated in an inverse correlation with insulin resistance $[32,33]$. Leptin regulates the appetite, and high levels of leptin induced by subcutaneous fat accumulation may indicate decreased leptin sensitivity in obese individuals [34]. Finally, high levels of free fatty acids associated with obesity contribute to the development of peripheral insulin resistance [35].

Advanced glycation end products (AGEs) are a result of the nonenzymatic reactions between sugars and amino groups such as proteins and lipids [36]. As some AGEs have typical fluorescence bands [37], skin autofluorescence can be used as a robust noninvasive biomarker of AGE accumulation in tissues [38]. AGEs accumulate with age in healthy individuals and have been observed to accumulate faster in people with diabetes and inflammatory diseases [39]. AGEs can predict the severity of complications in diabetes [40]. The inclusion of skin autofluorescence in the Finnish Diabetes Risk Score improved the ability to detect undiagnosed diabetes and reclassify people in the intermediate risk category [41].

\section{Cell Blood Count}

A decrease in blood hemoglobin with age and anemia in older people is associated with functional and cognitive impairment as well as mortality [42,43]. In addition, studies on biological age modelling often include hemoglobin and hematocrit as biomarkers of aging due to their correlation with age $[18,44]$. Therefore, we included hemoglobin and hematocrit as candidate variables for the biological age model despite the notion that anemia is not a physiological finding related to aging per se but is associated with nutrient-related iron deficiency or unexplained anemia [45].

\section{Cardiorespiratory Function}

Blood pressure is a biomarker of cardiovascular (CV) function and is one of the most important modifiable risk factors that strongly predicts CV morbidity and mortality [46]. High blood pressure is a common medical condition, and its prevalence increases with age [47]. As excess fat mass represents the major factor predisposing high blood pressure, lifestyle interventions targeting obesity (and smoking) are highly relevant [48]. Forced expiratory volume in 1 second $\left(\mathrm{FEV}_{1}\right)$, forced vital capacity (FVC), and the $\mathrm{FEV}_{1}$-FVC ratio are biomarkers of dynamic lung function [49]. $\mathrm{FEV}_{1}$ declines in a nonlinear manner with age, with the estimated decline of 25-30 mL/year starting at the age of 35-40 years and increasing up to $60 \mathrm{~mL} /$ year after the age of 70 years; however, the interindividual variability can be considerable [49].

\section{Physical Capacity}

A main indicator of physical activity and cardiorespiratory fitness is maximal oxygen uptake $\left(\mathrm{VO}_{2 \max }\right)$. Functional independence is dependent on $\mathrm{VO}_{2 \max }$ [50], and its association with mortality and morbidity of noncommunicable diseases is well established [5]. Aging is associated with a decline in $\mathrm{VO}_{2 \max }$ (about $6.2 \% /$ decade) [51], primarily due to a reduction in maximal cardiac output and, secondly, due to a reduced oxygen extraction capacity at the muscle level (maximal arteriovenous oxygen difference) [52,53]. Importantly, the decline in $\mathrm{VO}_{2 \max }$ is decelerated in trained compared to sedentary subjects [54]. Finally, physical inactivity accelerates secondary aging by reduction in $\mathrm{VO}_{2 \max }$, skeletal muscle strength, and bone mineral density [55]. A Norwegian study found that sedentary time increased by 4.4 and $3.2 \mathrm{~min} /$ day for women and men, respectively from the age of 65 years, concomitant with a decrease in both low and moderate to vigorous physical activity [56]. Handgrip strength is a robust measure of overall strength, which correlates with mortality and declines in a linear manner with age $(0.34$ and $0.65 \mathrm{~kg} / \mathrm{year}$ for women and men, respectively) [57,58]. Knee extension and elbow flexion are associated with functional independence and health. They are important for daily activities and have been used in previous epidemiological health investigations $[59,60]$. The sit to stand test is part of the "Short Physical Performance Battery" [61], which assesses lower extremity function and predicts disability in older age $[59,62]$.

\section{Immune Function}

Adipose tissue is an endocrine organ and a major regulator of inflammation [63]. Excess adipose tissue is an important contributor to the elevated C-reactive protein (CRP) concentrations observed in obese people [64] and is related to the production of interleukin 6 (IL-6) and its stimulation of hepatic CRP production [65]. Chronically elevated levels of pro-inflammatory markers such as IL-6 and tumor necrosis factor- $\alpha$ are also key features of the aging phenotype defined as "inflammaging" [66]. Chronic low-grade inflammation (LGI) is thought to be part of the T2DM [67], CVD [68], cancer [69], and Alzheimer disease [70] pathophysiologies. CRP is considered a gold standard biomarker of low-grade inflammation and chronic inflammation. Recently, soluble urokinase plasminogen activator receptor (suPAR) was proposed as a biomarker of inflammation and was shown to predict T2DM, CVD, and cancer independently of CRP [71]. Plasma suPAR concentration increases with aging and unhealthy lifestyles (eg, unhealthy dieting and smoking) [71,72].

\section{Measurements and Procedure}

The examination was conducted in the order described below. Arterial blood pressure was measured in triplicate in the supine position using an automatic monitor (BoSo Medicus Control, $\mathrm{BOSCH}+\mathrm{SOHN} \mathrm{GmbH)}$. Venous blood samples were obtained for measuring concentrations of total cholesterol, high- and low-density lipoproteins, triglycerides, glucose, insulin, adiponectin, glycated hemoglobin $\left(\mathrm{HbA}_{1 \mathrm{c}}\right)$, hematocrit, hemoglobin, CRP, and suPAR. Body composition was assessed by dual-energy X-ray absorptiometry scanning and visceral fat measurements using the CoreScan software (Lunar Prodigy Advanced, Lunar). Body composition was also assessed by bio-impedance (MC-780MA, Tanita Corporation of America Inc), which is commonly used in clinical settings. Measures of waist and hip circumference were collected. A high-quality 
portrait picture was taken for a subanalysis on perceived age. Skin autofluorescence was measured by an AGE Reader (DiagnOptics BV). Lung function was assessed in terms of $\mathrm{FEV}_{1}$ and FVC (Vyntus SPIRO spirometer, Vyaire Medical). We tested three isometric strength measures. The first test involved measuring knee extension strength. The participant was made to sit on a table. The test was performed with one leg, with the knee in $90^{\circ}$ flexion serving as the starting position while the thigh was stabilized against the table with a standard gait belt so that it could not be lifted during the test. A standardized belt stabilization configuration was used to position the dynamometer (microFET2, Hoggan Health Industries) against the back of the table leg using a flat attachment. This method has been validated against the "gold standard" isokinetic dynamometer [73]. The second test involved measuring handgrip strength. Keeping the arm by the side, the participant was asked to squeeze a handgrip dynamometer (Takei Digital Hand Grip Dynamometer, Takei Scientific Instruments Co, Ltd). The third test measured bicep strength. The participants were asked to keep both arms by the side and flex both elbows by $90^{\circ}$ using a Takei TKK 5402 Digital Back Strength Dynamometer (Takei Scientific Instruments Co, Ltd, Tokyo). Participants performed a minimum of 3 test trials and continued until no increase in strength occurred. A graded exercise test (Quark PFT Ergo, Cosmed) was conducted to determine $\mathrm{VO}_{2 \max }$ with an electromagnetically braked cycle ergometer (Lode Excalibur, Groeningen). The exercise protocol consisted of 5 minutes of warm-up time at 50 and $100 \mathrm{~W}$ for females and males, respectively, followed by a $25 \mathrm{~W}$ increase in load every minute until voluntary exhaustion. Finally, the participants filled out the quality of life (SF-12v2 Health Survey) and Physical Activity Score (PAS 2.1) questionnaires [74], and their education level and smoking habits were recorded.

\section{Phase 2: BA Estimation}

\section{Mathematical Approach}

The three most common approaches to estimate biological age are (1) multiple linear regression (MLR) [14,75-78]; (2) principal component analysis (PCA) [19,44,79-82]; and (3) Klemera and Doubals' method (KDM) $[83,84]$. Each method has its own benefits and limitations and has been compared substantially in the literature $[17,18,85]$. The MLR method is considered the basic approach to estimate biological age but is criticized for over- and underestimating biological age at each end of the age spectrum and the risk of biomarker multicollinearity. The PCA method derives from MLR but uses the first principal component from the PCA to form the biological age equation. This reduces the over- and underestimation observed in the MLR method and resolves the risk of multicollinearity [79]. In comparison with the MLR and PCA approaches, the KDM is a comprehensive mathematical approach. The biological age estimation is based on minimizing the distance between $m$ regression lines and $m$ biomarker points within an $m$-dimensional space of all included biomarkers [83]. Although the biological age estimated by the KDM has been shown to predict mortality better than that estimated by MLR and PCA [18], the majority of the studies on biological age models using minimally invasive biomarkers (essential for the use of a biological age model in health promotion) have been conducted using PCA [86]. Therefore, we will use PCA in our model development. Doing so will also allow a wider comparison of our results against more data and the findings of prior studies that had applied this approach to their models, thus facilitating an evaluation of the external validity of our model.

PCA was originally proposed by Nakamura et al [79] to select the fewest possible physiological variables to estimate biological age. Biological age construction when applying PCA includes (1) selection of the variables using correlation analysis, redundancy assessment, and loss of informative value caused by internal consistency among the variables; (2) use of PCA to obtain the principal components; (3) application of the first principal component to develop the normalized biological age score; and (4) transformation of the normalized biological age score into biological age expressed in years so that it is comparable with the chronological age [79,86]. The mathematical and statistical analysis will be completed using SAS Enterprise Guide 7.1 and MATLAB R2018b.

\section{Phase 3: Validation Cohort}

\section{Study Design}

We intend to recruit overweight and obese subjects as obesity increases the risk of age-related diseases early in life. Thus, individuals with obesity are expected to deviate from the pathway of a healthy aging phenotype, resulting in a higher biological age compared to chronological age. Recruitment for the study will commence at a Danish folk high school conducting lifestyle interventions. We seek to recruit 80 overweight or obese adults ( $\geq 18$ years) attending a 15 -week lifestyle intervention course. Pregnancy, history of CVD, and using $\beta$-blockers are the exclusion criteria for participation in the study. The aim of the lifestyle intervention is an $8 \%-10 \%$ weight loss. Initial moderate weight loss induces improvements in most CV risk factors $[87,88]$. Therefore, this setting will allow us to explore the clinical relevance of the biological age model in assessing healthy aging. The intensive lifestyle intervention includes key features to achieve healthy aging and compress morbidity. Daily activities from 7 AM to 4 PM include supervised training (1-3 hour/day), class-based theoretical teaching focusing on changes to healthy behavior, and individual cognitive therapy. Participants are served healthy hypocaloric diets, individually prepared in accordance to an energy balance required for a normal BMI of $25 \mathrm{~kg} / \mathrm{m}^{2}$. For more information on the intensive lifestyle intervention, refer to the work of Dandanell et al [89].

\section{Measurements and Procedure}

The results from the PCA will determine the measures to be included in the protocol. The procedure will be similar to the one described in the Phase 1 study, with the exception that we will use the short version (4 generic items) of the International Physical Activity Questionnaire and a modified exercise protocol to assess $\mathrm{VO}_{2 \max }$. To ensure that the exercise protocol elicits a valid $\mathrm{VO}_{2 \max }$, warm up will be performed at 30 and $50 \mathrm{~W}$ for women and men, respectively, and thereafter increased by 20 and $25 \mathrm{~W}$ every minute until exhaustion for women and men, respectively. Biological age will be estimated at the beginning 
and end of the course based on the results of the PCA. In addition, we will estimate the metabolic syndrome and Framingham risk score in the validation cohort [90,91]. Doing so will allow us to evaluate the response variation in biological age after an expected moderate weight loss and improved aerobic capacity, and we will compare these results with the changes observed in the existing validated health metrics used in health promotion and disease prevention (Framingham risk score and metabolic syndrome) [92,93]. Furthermore, we will (1) compare the biological age results in the healthy study population (the derivation cohort) with the overweight study population (the validation cohort) and (2) evaluate our biological age model against existing models to assess the feasibility of the former for health promotion.

\section{Results}

\section{Phase 1}

The derivation cohort consists of 51 women and 49 men. The distributions of their demographic and clinical characteristics are presented in Tables 1 and 2 .

Table 1. Characteristics of study participants in the derivation cohort.

\begin{tabular}{|c|c|c|}
\hline Variables & Women $(n=51)$ & Men $(n=49)$ \\
\hline \multicolumn{3}{|l|}{ Age groups (years), n (\%) } \\
\hline $18-23$ & $7(13.7)$ & $6(12.2)$ \\
\hline $24-29$ & $7(13.7)$ & $6(12.2)$ \\
\hline $30-35$ & $6(11.7)$ & $7(14.3)$ \\
\hline $36-41$ & $6(11.8)$ & $6(12.2)$ \\
\hline $42-47$ & $6(11.8)$ & $6(12.2)$ \\
\hline $48-53$ & $6(11.8)$ & $6(12.2)$ \\
\hline $54-59$ & $7(13.7)$ & $6(12.2)$ \\
\hline $60-65$ & $6(11.8)$ & $6(12.2)$ \\
\hline \multicolumn{3}{|l|}{ BMI $\left(\mathrm{kg} / \mathrm{m}^{2}\right), \mathrm{n}(\%)$} \\
\hline$<25$ & $33(64.7)$ & $27(55.1)$ \\
\hline$\geq 25$ & $13(25.5)$ & $21(42.9)$ \\
\hline$\geq 30$ & $5(9.8)$ & $1(2.0)$ \\
\hline $\mathrm{HbA}_{1 \mathrm{c}}{ }^{\mathrm{a}}(\mathrm{mmol} / \mathrm{mol})$, mean $(\mathrm{SD})$ & $32.3(3.2)$ & $33.4(3.1)$ \\
\hline Lung function $-\mathrm{FEV}_{1} / \mathrm{FVC}(\%)$, mean (SD) & $79.4(6.0)$ & $79.1(5.3)$ \\
\hline \multicolumn{3}{|l|}{ Physical activity $^{\mathbf{b}}$ (min/week), n (\%) } \\
\hline$\geq 150$ & $41(80.4)$ & $46(93.9)$ \\
\hline$<150$ & $10(19.6)$ & $3(6.1)$ \\
\hline \multicolumn{3}{|l|}{ Education $^{\mathrm{c}}$ (years), n (\%) } \\
\hline$<10^{\mathrm{d}}$ & $0(0.0)$ & $3(7.5)$ \\
\hline $10-12^{\mathrm{e}}$ & $32(69.6)$ & $29(72.5)$ \\
\hline$\geq 13^{\mathrm{f}}$ & $14(30.4)$ & $8(20)$ \\
\hline \multicolumn{3}{|l|}{ Smoking status, n (\%) } \\
\hline Yes & $3(5.9)$ & $3(6.1)$ \\
\hline No & 48 (94.1) & 46 (93.9) \\
\hline
\end{tabular}

${ }^{\mathrm{a}} \mathrm{HbA}_{1 \mathrm{c}}$ : Hemoglobin $\mathrm{A}_{1 \mathrm{c}}$.

${ }^{\mathrm{b}}$ Leisure-time spent on moderate (5 metabolic equivalents) and vigorous (6 metabolic equivalents) physical activity.

${ }^{c}$ Level of education was reported by $86.0 \%$ (86/100) of the total study population (46/100, 46.0\% women; 40/100, 40.0\% men).

${ }^{\mathrm{d}}$ Lower secondary education.

${ }^{\mathrm{e}}$ Upper secondary education.

${ }^{\mathrm{f}}$ First- and second-stage tertiary education. 
Table 2. Maximal oxygen consumption of study participants in the derivation cohort.

\begin{tabular}{lll}
\hline Age group (years) & $\operatorname{VO}_{2 \max }{ }^{\mathrm{a}}(\mathrm{mL} / \mathrm{min} / \mathrm{kg})$, mean $(\mathrm{SD})$ & \\
& Women $(\mathrm{n}=51)$ & Men $(\mathrm{n}=49)$ \\
\hline $18-23$ & $36.9(7.3)$ & $45.2(4.0)$ \\
$24-29$ & $37.4(2.5)$ & $44.8(7.8)$ \\
$30-35$ & $37.7(5.6)$ & $47.9(7.8)$ \\
$36-41$ & $36.0(7.8)$ & $43.2(7.7)$ \\
$42-47$ & $39.7(7.4)$ & $47.1(6.5)$ \\
$48-53$ & $29.8(4.7)$ & $42.7(6.0)$ \\
$54-59$ & $30.1(3.9)$ & $39.7(9.8)$ \\
$60-65$ & $31.8(4.6)$ & $40.1(4.1)$ \\
\hline
\end{tabular}

${ }^{\mathrm{a}} \mathrm{VO}_{2 \max }$ : Maximal oxygen consumption.

The majority of the participants reported having an upper secondary education (eg, high school diploma; women: 32/46, 69.6\% ; men: 29/40, 72.5\%). Very few within the cohort (6/100, $6 \%$ in total) smoked. Cardiorespiratory fitness $\left(\mathrm{VO}_{2 \max }\right)$ was moderate to high in women and men throughout the age range, the majority (women, 41/51, 80.4\%; men, 46/49, 93.9\%) adhering to the national recommendations of a minimum of 150 $\mathrm{min} /$ week of moderate to vigorous physical activity [94]. No indications of decreased lung function or T2DM were found.
Although free from diseases, we found variations in metabolic health when assessing the cohort in terms of metabolic syndrome. Metabolic syndrome was present in 3 women and 2 men. The distribution of risk factors related to metabolic syndrome are visualized in Figure 2. We used the definition provided by the International Diabetes Federation to assess metabolic syndrome [31].

Figure 2. Health profile in relation to metabolic syndrome variables. The triangles represent women, and the circles represent men. Three women (yellow, orange, and purple triangles) and two men (red and blue circles) fulfilled the criteria for metabolic syndrome. The solid lines represent the mean (SD) for each group. The dashed lines represent the cut-off criteria (values mentioned in the brackets that follow) for each variable in accordance with the definition provided by the International Diabetes Federation. A: Waist circumference in females ( $\geq 80 \mathrm{~cm})$ and males $(\geq 94 \mathrm{~cm})$; B: Systolic blood pressure ( $\geq 130 \mathrm{~mm} \mathrm{Hg}$ ); C: Diastolic blood pressure ( $\geq 85 \mathrm{~mm} \mathrm{Hg}$ ); D: Fasting plasma glucose ( $\geq 5.6 \mathrm{mmol} / \mathrm{L})$; E: High-density lipoprotein (HDL) for females ( $1.29 \mathrm{mmol} / \mathrm{L})$ and males $(1.03 \mathrm{mmol} / \mathrm{L})$; F: Triglycerides $(\geq 1.7 \mathrm{mmol} / \mathrm{L})$.
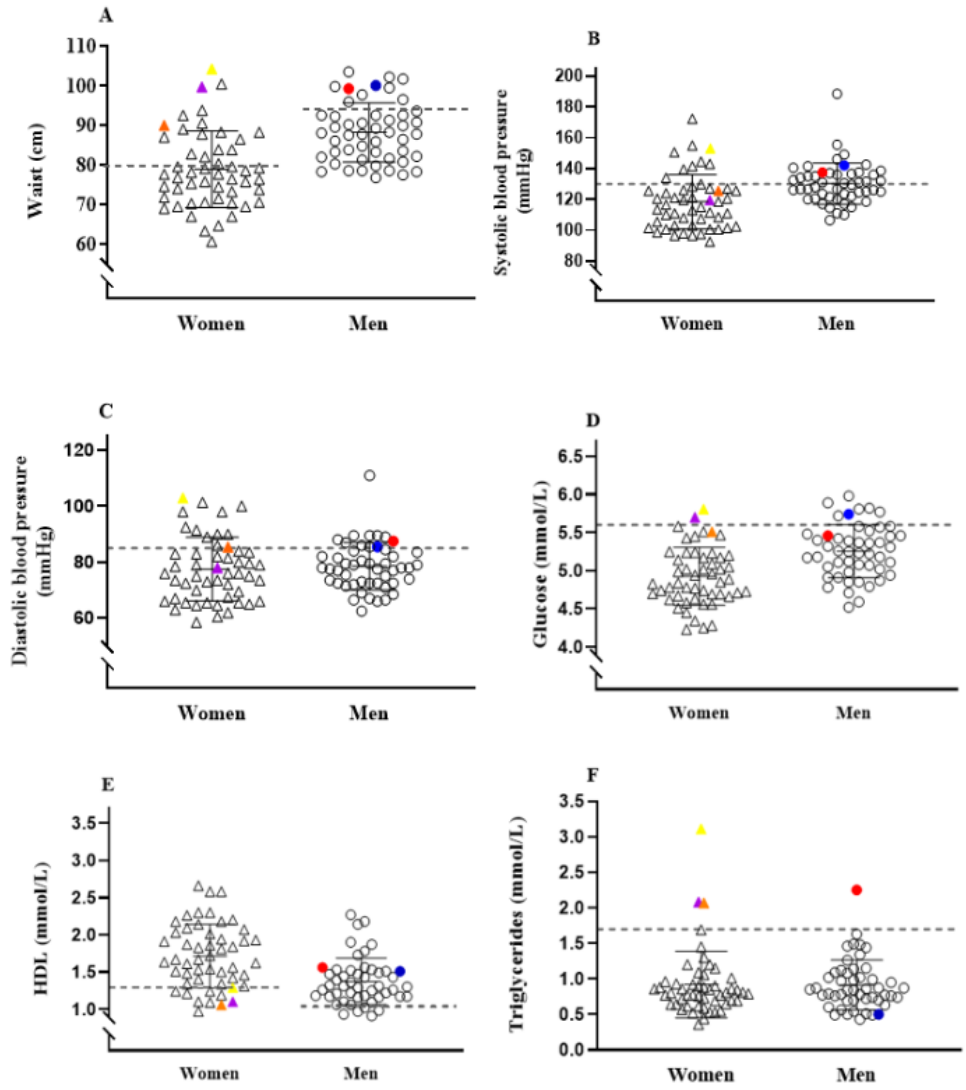


\section{Phase 2}

Correlation analysis and principal component analysis have been performed. Interpretation of the model, including sensitivity analysis, internal consistency reliability, and model refinement, will follow.

\section{Phase 3}

This study has been approved by the Local Research Ethics Committee, Copenhagen, Denmark (H-19073643; Clinical Trial Number NCT04279366). We have established collaboration with the staff at the folk high school and recruitment for participation is forthcoming.

\section{Discussion}

\section{Findings}

The primary objective of this pilot study was to develop a biological age model that could be applied for health promotion of the general adult population, given its ability to distinguish healthy and unhealthy aging trajectories among individuals with the same chronological age and sex. Within this objective lies the practical limitation of including as few and minimally invasive biomarkers in the model as possible despite the complexity of aging. Therefore, to develop a reliable biological age model, it is essential to select biomarkers that accurately show significant change with age, reflect the aging status independent of disease, have high reproducibility, cover essential areas of human function, and are appropriate for in vivo studies of humans $[15,79,95]$. A limitation of this study is that this biological age model is designed to assess a healthy aging trajectory only on a physical level; the assessment of the cognitive aspects of maintaining functional independence for a socially active life, an important part of the healthy aging phenotype, are not included herein [4]. Another limitation is that while the biomarkers included in the proposed biological age model align with the phenotypic biomarkers of aging (eg, clinical measures such as grip strength and glucose concentration), the model overlooks the molecular-based biomarkers of aging (ie, DNA-related markers). Short telomere length is associated with risk of CVD, age-related decline in physical function, and mortality [96]. Furthermore, DNA methylation, a biomarker for biological age (DNAm age, also referred to as the "epigenetic clock"), predicts all-cause mortality independent of the classic risk factors (age, body mass index, smoking, etc) as well as frailty, self-related health, and chronological age [96]. While such models seem promising, the lack of feasibility regarding use in community-based interventions is the main reason for not including these biomarkers in our biological age model. We do, however, plan to validate the biological age model against telomere length at a later time, when data from the derivation cohort become available. Our secondary objective involves investigating the usefulness of the model. Validating the model against mortality and morbidity is preferable but beyond the scope of this study. Instead, we plan to validate the clinical use of the model in Phase 3 by comparing the change in biological age against that in already validated prediction metrics commonly used in health promotion (eg, the Framingham risk score and metabolic syndrome) in relation to a lifestyle intervention. As the validation cohort is not randomly assigned from the general population, there is a risk that it might represent a selected group whose physiological state is independent of behavioral factors (eg, diet and physical activity) and biased by genetics. Regardless, the change in biological age after an intensive lifestyle intervention can provide initial evidence about the potential of the biological age model for health promoting interventions.

\section{Conclusions}

We expect to find that the biological age model is a useful indicator of the risk of metabolic dysfunction and disease. Given future challenges, our expectation calls for further optimization of the model (eg, extending the sample size of the derivation cohort) and validation (by including hard endpoints such as mortality and morbidity).

\section{Acknowledgments}

$\mathrm{KH}$ and JWH designed and conceptualized the study. KH, MF, and PH collected the data. KH and ABK analyzed the data. KH, $\mathrm{ABK}, \mathrm{K}-\AA \mathrm{H}$, JWH, and HBDS interpreted the data. KH wrote the first draft, and FD, HBDS, ABK, and JWH revised the manuscript. All authors read and approved the final manuscript. This work was supported by the Copenhagen Center for Health Technology, the Center for Healthy Aging, and University College Copenhagen. The sponsors had no involvement in the study design, writing of the manuscript, and choice of publication.

\section{Conflicts of Interest}

None declared.

\section{References}

1. Harper S. Economic and social implications of aging societies. Science 2014 Oct 31;346(6209):587-591. [doi: 10.1126/science.1254405] [Medline: 25359967]

2. Petsko GA. A seat at the table. Genome Biol 2008;9(12):113 [FREE Full text] [doi: 10.1186/gb-2008-9-12-113] [Medline: 19144208]

3. Fuchs J, Scheidt-Nave C, Hinrichs T, Mergenthaler A, Stein J, Riedel-Heller S, et al. Indicators for healthy ageing--a debate. Int J Environ Res Public Health 2013 Dec 02;10(12):6630-6644 [FREE Full text] [doi: 10.3390/ijerph10126630] [Medline: $\underline{24317381]}$ 
4. Lara J, Godfrey A, Evans E, Heaven B, Brown LJ, Barron E, et al. Towards measurement of the Healthy Ageing Phenotype in lifestyle-based intervention studies. Maturitas 2013 Oct;76(2):189-199 [FREE Full text] [doi: 10.1016/j.maturitas.2013.07.007] [Medline: 23932426]

5. Blair S, Sallis R, Hutber A, Archer E. Exercise therapy - the public health message. Scand J Med Sci Sports 2012 Aug;22(4):e24-e28. [doi: 10.1111/j.1600-0838.2012.01462.x] [Medline: 22429265]

6. Loef M, Walach $\mathrm{H}$. The combined effects of healthy lifestyle behaviors on all cause mortality: a systematic review and meta-analysis. Prev Med 2012 Sep;55(3):163-170. [doi: 10.1016/j.ypmed.2012.06.017] [Medline: 22735042]

7. Kohl HW, Craig CL, Lambert EV, Inoue S, Alkandari JR, Leetongin G, Lancet Physical Activity Series Working Group. The pandemic of physical inactivity: global action for public health. Lancet 2012 Jul 21;380(9838):294-305. [doi: 10.1016/S0140-6736(12)60898-8] [Medline: 22818941]

8. Sallis JF, Bull F, Guthold R, Heath GW, Inoue S, Kelly P, Lancet Physical Activity Series 2 Executive Committee. Progress in physical activity over the Olympic quadrennium. Lancet 2016 Sep 24;388(10051):1325-1336. [doi: 10.1016/S0140-6736(16)30581-5] [Medline: 27475270]

9. GBD 2015 Obesity Collaborators T, Afshin A, Forouzanfar MH, Reitsma MB, Sur P, Estep K, et al. Health effects of overweight and obesity in 195 countries over 25 years. N Engl J Med 2017 Jul 06;377(1):13-27 [FREE Full text] [doi: 10.1056/NEJMoa1614362] [Medline: 28604169]

10. What is Health Promotion? World Health Organization. URL: https://www.who.int/features/qa/health-promotion/en/ [accessed 2020-10-05]

11. Lowsky D, Olshansky S, Bhattacharya J, Goldman D. Heterogeneity in healthy aging. J Gerontol A Biol Sci Med Sci 2014 Jun;69(6):640-649 [FREE Full text] [doi: 10.1093/gerona/glt162] [Medline: 24249734]

12. Goffaux J, Friesinger GC, Lambert W, Shroyer LW, Moritz TE, McCarthy M, et al. Biological age--a concept whose time has come: a preliminary study. South Med J 2005 Oct;98(10):985-993. [doi: 10.1097/01.smj.0000182178.22607.47] [Medline: 16295813]

13. Comfort A. Test-battery to measure ageing-rate in man. The Lancet 1969 Dec;294(7635):1411-1415. [doi: 10.1016/s0140-6736(69)90950-7]

14. Hollingsworth JW, Hashizume A, Jablon S. Correlations between tests of aging in Hiroshima subjects--an attempt to define "physiologic age". Yale J Biol Med 1965 Aug;38(1):11-26 [FREE Full text] [Medline: 5841151]

15. Crimmins E, Vasunilashorn S, Kim JK, Alley D. Biomarkers related to aging in human populations. Adv Clin Chem 2008;46:161-216 [FREE Full text] [doi: 10.1016/s0065-2423(08)00405-8] [Medline: 19004190]

16. López-Otín C, Blasco MA, Partridge L, Serrano M, Kroemer G. The hallmarks of aging. Cell 2013 Jun 06;153(6):1194-1217 [FREE Full text] [doi: 10.1016/j.cell.2013.05.039] [Medline: 23746838]

17. Jee H, Park J. Selection of an optimal set of biomarkers and comparative analyses of biological age estimation models in Korean females. Arch Gerontol Geriatr 2017;70:84-91. [doi: 10.1016/j.archger.2017.01.005] [Medline: 28110151]

18. Levine ME. Modeling the rate of senescence: can estimated biological age predict mortality more accurately than chronological age? J Gerontol A Biol Sci Med Sci 2013 Jun;68(6):667-674 [FREE Full text] [doi: 10.1093/gerona/gls233] [Medline: 23213031]

19. Kang YG, Suh E, Lee J, Kim DW, Cho KH, Bae C. Biological age as a health index for mortality and major age-related disease incidence in Koreans: National Health Insurance Service - Health screening 11-year follow-up study. Clin Interv Aging 2018;13:429-436 [FREE Full text] [doi: 10.2147/CIA.S157014] [Medline: 29593385]

20. Lara J, Cooper R, Nissan J, Ginty AT, Khaw K, Deary IJ, et al. A proposed panel of biomarkers of healthy ageing. BMC Med 2015 Sep 15;13:222 [FREE Full text] [doi: 10.1186/s12916-015-0470-9] [Medline: 26373927]

21. Blehar MC, Spong C, Grady C, Goldkind SF, Sahin L, Clayton JA. Enrolling pregnant women: issues in clinical research. Womens Health Issues 2013 Jan;23(1):e39-e45 [FREE Full text] [doi: 10.1016/j.whi.2012.10.003] [Medline: 23312713]

22. Silva AM, Shen W, Heo M, Gallagher D, Wang Z, Sardinha LB, et al. Ethnicity-related skeletal muscle differences across the lifespan. Am J Hum Biol 2010;22(1):76-82 [FREE Full text] [doi: 10.1002/ajhb.20956] [Medline: 19533617]

23. Narici MV, Maganaris CN, Reeves ND, Capodaglio P. Effect of aging on human muscle architecture. J Appl Physiol (1985) 2003 Dec;95(6):2229-2234. [doi: 10.1152/japplphysiol.00433.2003] [Medline: 12844499]

24. Mitchell WK, Williams J, Atherton P, Larvin M, Lund J, Narici M. Sarcopenia, dynapenia, and the impact of advancing age on human skeletal muscle size and strength; a quantitative review. Front Physiol 2012;3:260 [FREE Full text] [doi: 10.3389/fphys.2012.00260] [Medline: 22934016]

25. Delmonico MJ, Beck DT. The current understanding of sarcopenia: Emerging tools and interventional possibilities. Am J Lifestyle Med 2017;11(2):167-181 [FREE Full text] [doi: 10.1177/1559827615594343] [Medline: 30202329]

26. Wei M, Gaskill S, Haffner S, Stern M. Waist circumference as the best predictor of noninsulin dependent diabetes mellitus (NIDDM) compared to body mass index, waist/hip ratio and other anthropometric measurements in Mexican Americans--a 7-year prospective study. Obes Res 1997 Jan;5(1):16-23. [doi: 10.1002/j.1550-8528.1997.tb00278.x] [Medline: 9061711]

27. Huxley R, Mendis S, Zheleznyakov E, Reddy S, Chan J. Body mass index, waist circumference and waist:hip ratio as predictors of cardiovascular risk--a review of the literature. Eur J Clin Nutr 2010 Jan;64(1):16-22 [FREE Full text] [doi: 10.1038/ejen.2009.68] [Medline: 19654593] 
28. Brewer RA, Gibbs VK, Smith DL. Targeting glucose metabolism for healthy aging. Nutr Healthy Aging 2016 Oct 27;4(1):31-46 [FREE Full text] [doi: 10.3233/NHA-160007] [Medline: 28035340]

29. Hildrum B, Mykletun A, Hole T, Midthjell K, Dahl AA. Age-specific prevalence of the metabolic syndrome defined by the International Diabetes Federation and the National Cholesterol Education Program: the Norwegian HUNT 2 study. BMC Public Health 2007 Aug 29;7:220 [FREE Full text] [doi: 10.1186/1471-2458-7-220] [Medline: 17727697]

30. Ford ES, Giles WH, Dietz WH. Prevalence of the metabolic syndrome among US adults: findings from the third National Health and Nutrition Examination Survey. JAMA 2002 Jan 16;287(3):356-359. [doi: 10.1001/jama.287.3.356] [Medline: 11790215]

31. Alberti KGMM, Zimmet P, Shaw J. Metabolic syndrome--a new world-wide definition. A Consensus Statement from the International Diabetes Federation. Diabet Med 2006 May;23(5):469-480. [doi: 10.1111/j.1464-5491.2006.01858.x] [Medline: $\underline{16681555]}$

32. Matsuzawa Y. Establishment of a concept of visceral fat syndrome and discovery of adiponectin. Proc Jpn Acad Ser B Phys Biol Sci 2010;86(2):131-141 [FREE Full text] [doi: 10.2183/pjab.86.131] [Medline: 20154470]

33. Yadav A, Kataria MA, Saini V, Yadav A. Role of leptin and adiponectin in insulin resistance. Clin Chim Acta 2013 Feb 18;417:80-84. [doi: 10.1016/j.cca.2012.12.007] [Medline: 23266767]

34. Considine RV, Sinha MK, Heiman ML, Kriauciunas A, Stephens TW, Nyce MR, et al. Serum immunoreactive-leptin concentrations in normal-weight and obese humans. N Engl J Med 1996 Feb 01;334(5):292-295. [doi: 10.1056/NEJM199602013340503] [Medline: 8532024]

35. Guilherme A, Virbasius JV, Puri V, Czech MP. Adipocyte dysfunctions linking obesity to insulin resistance and type 2 diabetes. Nat Rev Mol Cell Biol 2008 May;9(5):367-377 [FREE Full text] [doi: 10.1038/nrm2391] [Medline: 18401346]

36. Isami F, West BJ, Nakajima S, Yamagishi S. Association of advanced glycation end products, evaluated by skin autofluorescence, with lifestyle habits in a general Japanese population. J Int Med Res 2018 Mar;46(3):1043-1051. [doi: 10.1177/0300060517736914] [Medline: 29322837]

37. Ulrich P, Cerami A. Protein glycation, diabetes, and aging. Recent Prog Horm Res 2001;56:1-21. [doi: 10.1210/rp.56.1.1] [Medline: 11237208$]$

38. Mulder DJ, Water TVD, Lutgers HL, Graaff R, Gans RO, Zijlstra F, et al. Skin autofluorescence, a novel marker for glycemic and oxidative stress-derived advanced glycation endproducts: an overview of current clinical studies, evidence, and limitations. Diabetes Technol Ther 2006 Oct;8(5):523-535. [doi: 10.1089/dia.2006.8.523] [Medline: 17037967]

39. Nowotny K, Jung T, Höhn A, Weber D, Grune T. Advanced glycation end products and oxidative stress in type 2 diabetes mellitus. Biomolecules 2015 Mar 16;5(1):194-222 [FREE Full text] [doi: 10.3390/biom5010194] [Medline: 25786107]

40. Monnier V, Sell D, Genuth S. Glycation products as markers and predictors of the progression of diabetic complications. Ann N Y Acad Sci 2005 Jun;1043:567-581. [doi: 10.1196/annals.1333.065] [Medline: 16037280]

41. Fokkens B, van Waateringe R, Mulder D, Wolffenbuttel B, Smit A. Skin autofluorescence improves the Finnish Diabetes Risk Score in the detection of diabetes in a large population-based cohort: The LifeLines Cohort Study. Diabetes Metab 2018 Nov;44(5):424-430 [FREE Full text] [doi: 10.1016/j.diabet.2017.09.002] [Medline: 29097003]

42. Zakai NA, Katz R, Hirsch C, Shlipak MG, Chaves PHM, Newman AB, et al. A prospective study of anemia status, hemoglobin concentration, and mortality in an elderly cohort: the Cardiovascular Health Study. Arch Intern Med 2005 Oct 24;165(19):2214-2220. [doi: 10.1001/archinte.165.19.2214] [Medline: 16246985]

43. Mahlknecht U, Kaiser S. Age-related changes in peripheral blood counts in humans. Exp Ther Med 2010 Nov;1(6):1019-1025 [FREE Full text] [doi: 10.3892/etm.2010.150] [Medline: 22993635]

44. Nakamura E, Miyao K. A method for identifying biomarkers of aging and constructing an index of biological age in humans. J Gerontol A Biol Sci Med Sci 2007 Oct;62(10):1096-1105. [doi: 10.1093/gerona/62.10.1096] [Medline: 17921421]

45. Röhrig G, Gütgemann I, Kolb G, Leischker A. Anemia in the aged is not ageing related: position paper on anemia in the aged by the "working group anemia" of the German Geriatric Society (DGG). Eur Geriatr Med 2018 Apr 9;9(3):395-397. [doi: $10.1007 / \mathrm{s} 41999-018-0048-0]$

46. Lewington S, Clarke R, Qizilbash N, Peto R, Collins R, Prospective Studies Collaboration. Age-specific relevance of usual blood pressure to vascular mortality: a meta-analysis of individual data for one million adults in 61 prospective studies. Lancet 2002 Dec 14;360(9349):1903-1913. [doi: 10.1016/s0140-6736(02)11911-8] [Medline: 12493255]

47. Egan BM, Zhao Y, Axon RN. US trends in prevalence, awareness, treatment, and control of hypertension, $1988-2008$. JAMA 2010 May 26;303(20):2043-2050. [doi: 10.1001/jama.2010.650] [Medline: 20501926]

48. Beilin LJ, Puddey IB, Burke V. Lifestyle and hypertension. Am J Hypertens 1999 Sep;12(9 Pt 1):934-945. [doi: 10.1016/s0895-7061(99)00057-6] [Medline: 10509554]

49. Sharma G, Goodwin J. Effect of aging on respiratory system physiology and immunology. Clin Interv Aging 2006;1(3):253-260 [FREE Full text] [doi: 10.2147/ciia.2006.1.3.253] [Medline: $\underline{18046878}$ ]

50. Shephard RJ. Maximal oxygen intake and independence in old age. Br J Sports Med 2009 May;43(5):342-346. [doi: 10.1136/bjsm.2007.044800] [Medline: 18403414]

51. Aspenes ST, Nilsen TIL, Skaug EA, Bertheussen GF, Ellingsen $\varnothing$, Vatten L, et al. Peak oxygen uptake and cardiovascular risk factors in 4631 healthy women and men. Med Sci Sports Exerc 2011 Aug;43(8):1465-1473. [doi:

10.1249/MSS.0b013e31820ca81c] [Medline: 21228724] 
52. Stratton JR, Levy WC, Cerqueira MD, Schwartz RS, Abrass IB. Cardiovascular responses to exercise. Effects of aging and exercise training in healthy men. Circulation 1994 Apr;89(4):1648-1655. [doi: $\underline{10.1161 / 01 . c i r .89 .4 .1648]}$ [Medline: 8149532]

53. Hossack KF, Bruce RA. Maximal cardiac function in sedentary normal men and women: comparison of age-related changes. J Appl Physiol Respir Environ Exerc Physiol 1982 Oct;53(4):799-804. [doi: 10.1152/jappl.1982.53.4.799] [Medline: 7153117]

54. Ogawa T, Spina RJ, Martin WH, Kohrt WM, Schechtman KB, Holloszy JO, et al. Effects of aging, sex, and physical training on cardiovascular responses to exercise. Circulation 1992 Aug;86(2):494-503. [doi: 10.1161/01.cir.86.2.494] [Medline: 1638717]

55. Booth FW, Laye MJ, Roberts MD. Lifetime sedentary living accelerates some aspects of secondary aging. J Appl Physiol (1985) 2011 Nov;111(5):1497-1504. [doi: 10.1152/japplphysiol.00420.2011] [Medline: 21836048]

56. Hansen BH, Kolle E, Dyrstad SM, Holme I, Anderssen SA. Accelerometer-determined physical activity in adults and older people. Med Sci Sports Exerc 2012 Feb;44(2):266-272. [doi: 10.1249/MSS.0b013e31822cb354] [Medline: 21796052]

57. Frederiksen H, Hjelmborg J, Mortensen J, McGue M, Vaupel JW, Christensen K. Age trajectories of grip strength: cross-sectional and longitudinal data among 8,342 Danes aged 46 to 102. Ann Epidemiol 2006 Jul;16(7):554-562. [doi: 10.1016/j.annepidem.2005.10.006] [Medline: 16406245$]$

58. Sillanpää E, Laakkonen EK, Vaara E, Rantanen T, Kovanen V, Sipilä S, et al. Biological clocks and physical functioning in monozygotic female twins. BMC Geriatr 2018 Apr 04;18(1):83 [FREE Full text] [doi: 10.1186/s12877-018-0775-6] [Medline: 29614968]

59. Eriksen L, Grønbæk M, Helge JW, Tolstrup JS, Curtis T. The Danish Health Examination Survey 2007-2008 (DANHES 2007-2008). Scand J Public Health 2011 Mar;39(2):203-211. [doi: 10.1177/1403494810393557] [Medline: 21257645]

60. Arnold CM, Warkentin KD, Chilibeck PD, Magnus CRA. The reliability and validity of handheld dynamometry for the measurement of lower-extremity muscle strength in older adults. J Strength Cond Res 2010 Mar;24(3):815-824. [doi: 10.1519/JSC.0b013e3181aa36b8] [Medline: 19661831]

61. Guralnik JM, Simonsick EM, Ferrucci L, Glynn RJ, Berkman LF, Blazer DG, et al. A short physical performance battery assessing lower extremity function: association with self-reported disability and prediction of mortality and nursing home admission. J Gerontol 1994 Mar;49(2):M85-M94. [doi: 10.1093/geronj/49.2.m85] [Medline: $\underline{\text { 8126356] }}$

62. Guralnik JM, Ferrucci L, Simonsick EM, Salive ME, Wallace RB. Lower-extremity function in persons over the age of 70 years as a predictor of subsequent disability. N Engl J Med 1995 Mar 02;332(9):556-561. [doi:

10.1056/NEJM199503023320902] [Medline: 7838189]

63. Kershaw EE, Flier JS. Adipose tissue as an endocrine organ. J Clin Endocrinol Metab 2004 Jun;89(6):2548-2556. [doi: 10.1210/jc.2004-0395] [Medline: 15181022]

64. Aronson D, Bartha P, Zinder O, Kerner A, Markiewicz W, Avizohar O, et al. Obesity is the major determinant of elevated C-reactive protein in subjects with the metabolic syndrome. Int J Obes Relat Metab Disord 2004 May;28(5):674-679. [doi: 10.1038/sj.ijo.0802609] [Medline: 14993913]

65. Heinrich P, Castell J, Andus T. Interleukin-6 and the acute phase response. Biochem J 1990 Feb 01;265(3):621-636. [doi: 10.1042/bj2650621] [Medline: 1689567]

66. Starr ME, Evers BM, Saito H. Age-associated increase in cytokine production during systemic inflammation: adipose tissue as a major source of IL-6. J Gerontol A Biol Sci Med Sci 2009 Jul;64(7):723-730 [FREE Full text] [doi: 10.1093/gerona/glp046] [Medline: 19377014]

67. Shoelson SE, Lee J, Goldfine AB. Inflammation and insulin resistance. J Clin Invest 2006 Jul;116(7):1793-1801 [FREE Full text] [doi: 10.1172/JCI29069] [Medline: 16823477]

68. Hansson GK. Inflammation, atherosclerosis, and coronary artery disease. N Engl J Med 2005 Apr 21;352(16):1685-1695. [doi: 10.1056/NEJMra043430] [Medline: 15843671]

69. Balkwill F, Mantovani A. Inflammation and cancer: back to Virchow? Lancet 2001 Feb 17;357(9255):539-545. [doi: 10.1016/S0140-6736(00)04046-0] [Medline: 11229684]

70. Heneka MT, O'Banion MK. Inflammatory processes in Alzheimer's disease. J Neuroimmunol 2007 Mar;184(1-2):69-91. [doi: 10.1016/j.jneuroim.2006.11.017] [Medline: 17222916]

71. Eugen-Olsen J, Andersen O, Linneberg A, Ladelund S, Hansen T, Langkilde A, et al. Circulating soluble urokinase plasminogen activator receptor predicts cancer, cardiovascular disease, diabetes and mortality in the general population. $\mathrm{J}$ Intern Med 2010 Sep;268(3):296-308. [doi: 10.1111/j.1365-2796.2010.02252.x] [Medline: 20561148]

72. Haupt TH, Kallemose T, Ladelund S, Rasmussen LJH, Thorball CW, Andersen O, et al. Risk Factors Associated with Serum Levels of the Inflammatory Biomarker Soluble Urokinase Plasminogen Activator Receptor in a General Population. Biomark Insights 2014 Dec 16;9:BMI.S19876. [doi: 10.4137/bmi.s19876]

73. Hansen E, McCartney C, Sweeney R, Palimenio M, Grindstaff T. Hand-held dynamometer positioning impacts discomfort during quadriceps strength testing: A validity and reliability study. Int J Sports Phys Ther 2015 Feb;10(1):62-68 [FREE Full text] [Medline: 25709864]

74. Aadahl M, Jørgensen T. Validation of a new self-report instrument for measuring physical activity. Med Sci Sports Exerc 2003 Jul;35(7):1196-1202. [doi: 10.1249/01.MSS.0000074446.02192.14] [Medline: 12840642] 
75. Dubina T, Mints AYa, Zhuk E. Biological age and its estimation. III. Introduction of a correction to the multiple regression model of biological age in cross-sectional and longitudinal studies. Exp Gerontol 1984;19(2):133-143. [doi: 10.1016/0531-5565(84)90016-0] [Medline: 6610563]

76. Dubina T, Dyundikova V, Zhuk E. Biological age and its estimation. II. Assessment of biological age of albino rats by multiple regression analysis. Exp Gerontol 1983;18(1):5-18. [doi: 10.1016/0531-5565(83)90046-3] [Medline: 6873212]

77. Bae C, Kang YG, Kim S, Cho C, Kang HC, Yu BY, et al. Development of models for predicting biological age (BA) with physical, biochemical, and hormonal parameters. Arch Gerontol Geriatr 2008;47(2):253-265. [doi: 10.1016/j.archger.2007.08.009] [Medline: $\underline{17889950]}$

78. Bae C, Kang YG, Piao M, Cho B, Cho KH, Park YK, et al. Models for estimating the biological age of five organs using clinical biomarkers that are commonly measured in clinical practice settings. Maturitas 2013 Jul;75(3):253-260. [doi: 10.1016/j.maturitas.2013.04.008] [Medline: 23642770]

79. Nakamura E, Miyao K, Ozeki T. Assessment of biological age by principal component analysis. Mech Ageing Dev 1988 Dec;46(1-3):1-18. [doi: 10.1016/0047-6374(88)90109-1] [Medline: 3226152]

80. Zhang W, Bai X, Sun X, Cai G, Bai X, Zhu S, et al. Construction of an integral formula of biological age for a healthy Chinese population using principle component analysis. J Nutr Health Aging 2014;18(2):137-142. [doi: 10.1007/s12603-013-0345-8] [Medline: 24522464]

81. Zhang W, Jia L, Cai G, Shao F, Lin H, Liu Z, et al. Model construction for biological age based on a cross-sectional study of a healthy Chinese Han population. J Nutr Health Aging 2017;21(10):1233-1239. [doi: 10.1007/s12603-017-0874-7] [Medline: 29188884]

82. Park J, Cho B, Kwon H, Lee C. Developing a biological age assessment equation using principal component analysis and clinical biomarkers of aging in Korean men. Arch Gerontol Geriatr 2009;49(1):7-12. [doi: 10.1016/j.archger.2008.04.003] [Medline: 18597867$]$

83. Klemera P, Doubal S. A new approach to the concept and computation of biological age. Mech Ageing Dev 2006 Mar;127(3):240-248. [doi: 10.1016/j.mad.2005.10.004] [Medline: 16318865]

84. Mitnitski A, Howlett SE, Rockwood K. Heterogeneity of human aging and its assessment. J Gerontol A Biol Sci Med Sci 2017 Jul 01;72(7):877-884 [FREE Full text] [doi: 10.1093/gerona/glw089] [Medline: 27216811]

85. Cho IH, Park KS, Lim CJ. An empirical comparative study on biological age estimation algorithms with an application of Work Ability Index (WAI). Mech Ageing Dev 2010 Feb;131(2):69-78. [doi: 10.1016/j.mad.2009.12.001] [Medline: $\underline{20005245]}$

86. Jia L, Zhang W, Chen X. Common methods of biological age estimation. Clin Interv Aging 2017; 12:759-772 [FREE Full text] [doi: 10.2147/CIA.S134921] [Medline: 28546743]

87. Knowler WC, Barrett-Connor E, Fowler SE, Hamman RF, Lachin JM, Walker EA, Diabetes Prevention Program Research Group. Reduction in the incidence of type 2 diabetes with lifestyle intervention or metformin. N Engl J Med 2002 Feb 07;346(6):393-403 [FREE Full text] [doi: 10.1056/NEJMoa012512] [Medline: 11832527]

88. Pasanisi F, Contaldo F, de Simone G, Mancini M. Benefits of sustained moderate weight loss in obesity. Nutr Metab Cardiovasc Dis 2001 Dec;11(6):401-406. [Medline: 12055705]

89. Dandanell S, Skovborg C, Præst CB, Kristensen K, Nielsen M, Lionett S, et al. Maintaining a clinical weight loss after intensive lifestyle intervention is the key to cardiometabolic health. Obes Res Clin Pract 2017;11(4):489-498. [doi: 10.1016/j.orcp.2016.09.009] [Medline: 27720417]

90. Wolf PA, D'Agostino RB, Belanger AJ, Kannel WB. Probability of stroke: a risk profile from the Framingham Study. Stroke 1991 Mar;22(3):312-318. [doi: 10.1161/01.str.22.3.312] [Medline: 2003301]

91. Reaven GM. Role of insulin resistance in human disease (syndrome X): an expanded definition. Annu Rev Med 1993;44:121-131. [doi: 10.1146/annurev.me.44.020193.001005] [Medline: 8476236]

92. Sundström J, Risérus U, Byberg L, Zethelius B, Lithell H, Lind L. Clinical value of the metabolic syndrome for long term prediction of total and cardiovascular mortality: prospective, population based cohort study. BMJ 2006 Apr 15;332(7546):878-882 [FREE Full text] [doi: 10.1136/bmj.38766.624097.1F] [Medline: 16510492]

93. Jahangiry L, Farhangi MA, Rezaei F. Framingham risk score for estimation of 10-years of cardiovascular diseases risk in patients with metabolic syndrome. J Health Popul Nutr 2017 Nov 13;36(1):36 [FREE Full text] [doi: 10.1186/s41043-017-0114-0] [Medline: 29132438]

94. World Health Organization. Physical Activity and Adults Fact Sheet. Global Strategy on Diet, Physical Activity and Health. URL: https://www.who.int/dietphysicalactivity/factsheet adults/en/ [accessed 2020-10-05]

95. Baker GT, Sprott RL. Biomarkers of aging. Exp Gerontol 1988;23(4-5):223-239. [doi: 10.1016/0531-5565(88)90025-3] [Medline: 3058488 ]

96. Jylhävä J, Pedersen NL, Hägg S. Biological age predictors. EBioMedicine 2017 Jul;21:29-36 [FREE Full text] [doi: 10.1016/j.ebiom.2017.03.046] [Medline: 28396265]

\section{Abbreviations}

AGEs: advanced glycation end products 
CV: cardiovascular

CVD: cardiovascular disease

CRP: C-reactive protein

$\mathbf{F E V}_{\mathbf{1}}$ : forced expiratory volume in 1 second

FVC: forced vital capacity

$\mathbf{H b}_{\text {A1c }}$ : glycated hemoglobin

IL-6: interleukin 6

KDM: Klemera and Doubals' method

MLR: multiple linear regression

PAS: physical activity score

PCA: principal component analysis

suPAR: soluble urokinase Plasminogen Activator Receptor

T2DM: type 2 diabetes mellitus

$\mathbf{V O}_{2 \text { max }}$ : maximal oxygen uptake

Edited by $G$ Eysenbach; submitted 08.04.20; peer-reviewed by F Gomez; comments to author 10.07.20; revised version received 16.09.20; accepted 30.09.20; published 26.10.20

Please cite as:

Husted KLS, Fogelstrøm M, Hulst P, Brink-Kjer A, Henneberg KÅ, Sorensen HBD, Dela F, Helge JW

A Biological Age Model Designed for Health Promotion Interventions: Protocol for an Interdisciplinary Study for Model Development JMIR Res Protoc 2020;9(10):e19209

URL: http://www.researchprotocols.org/2020/10/e19209/

doi: $\underline{10.2196 / 19209}$

PMID: 33104001

CKarina Louise Skov Husted, Mathilde Fogelstrøm, Pernille Hulst, Andreas Brink-Kjær, Kaj-Åge Henneberg, Helge Bjarup Dissing Sorensen, Flemming Dela, Jørn Wulff Helge. Originally published in JMIR Research Protocols (http://www.researchprotocols.org), 26.10.2020. This is an open-access article distributed under the terms of the Creative Commons Attribution License (https://creativecommons.org/licenses/by/4.0/), which permits unrestricted use, distribution, and reproduction in any medium, provided the original work, first published in JMIR Research Protocols, is properly cited. The complete bibliographic information, a link to the original publication on http://www.researchprotocols.org, as well as this copyright and license information must be included. 